\title{
CANNABis, RECONCILIATION, AND THE RightS OF INDIGENOUS PEOPLES: Prospects AND CHALlENGES FOR CANNABIS LEgalizATION IN CANADA
}

\author{
KONSTANTIA KOUTOUKI* AND KATHERINE LOFTS ${ }^{* *}$
}

\begin{abstract}
The provisions of the federal Cannabis Act came into force on 17 October 2018, opening a new era of cannabis management in Canada. We examine cannabis in Canada through the lens of reconciliation and the rights of First Nations, Métis, and Inuit peoples. There is potential for Indigenous communities to benefit from cannabis legalization, but also a very real risk that the new legal framework will simply perpetuate existing injustices. We show that the new legislation is inadequate both in terms of lack of consultation with Indigenous communities, as well as in terms of substantive provisions - and omissions - in the legislation itself.
\end{abstract}

\section{TABLE OF CONTENTS}

I. INTRODUCTION . . . . . . . . . . . . . . . . . . . . . . . . 709

II. CONTINGENT DEFINITIONS OF CANNABIS AND THE

IMPLICATIONS FOR INDIGENOUS AND LOCAL COMMUNITIES

OF CANNABIS REGULATION UNDER INTERNATIONAL LAW . . . . . . . . . . 711

III. THE USE AND REGULATION OF CANNABIS

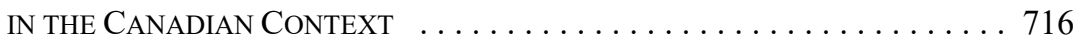

IV. CANNABis LEgalization, ReCONCILIATION, AND THE

RightS OF INDIGENOUS PEOPLES IN CANADA . . . . . . . . . . . . . . 720

V. CONCLUSION ............................... 727

\section{INTRODUCTION}

Over a long weekend in May 2018, hundreds gathered on Tyendinaga Mohawk Territory, near the town of Belleville, Ontario, for the first annual Indigenous Cannabis Cup. In addition to the competition for "the best bud in all of Turtle Island," the event website promised participants an action-packed schedule, including "overnight camping, bonfires, a wide range of workshops ranging from the practical to the esoteric, music and entertainment, a traditional social, [and] the construction and smoking of the world's largest peace pipe."1

The Indigenous Cannabis Cup was the first 100 percent Indigenous organized, owned, and operated cannabis industry event of its size,$^{2}$ and came on the cusp of Canada's legalization

Professor, Faculty of Law, Université de Montréal; Lead Counsel for Natural Resources, Centre for International Sustainable Development Law at McGill University; Executive Director, Nomomente Institute.

Director of Research and Programmes, Nomomente Institute.

Indigenous Cannabis Cup, “About," online: $<$ https://indigenouscannabiscup.com/about-the-cup/>.

Indigenous Cannabis Cup, "Mohawk Territory Makes History with Indigenous Cannabis Cup" (18 May 2018), online: <https://indigenouscannabiscup.com/2018/05/18/mohawk-territory-makes-history-withindigenous-cannabis-cup/> [ICC, "Mohawk Territory Makes History"]. 
of cannabis ${ }^{3}$ - the fulfillment of one of the key campaign promises of Justin Trudeau's Liberal Party during the 2015 federal election. ${ }^{4}$ In addition to celebrating the recreational aspects of cannabis use, the gathering emphasized the use of cannabis as medicine and a source of healing. It also provided a forum for Indigenous cannabis cultivators to share knowledge and expertise with each other, and sought to highlight the tremendous opportunities for Indigenous communities in the cannabis industry. For Cup founder Jamie Kunkel, a Tyendinaga Mohawk, cannabis legalization represents "a turning point of possibility for Indigenous peoples' economic self-determination, alongside that of other peoples historically experienced with the plant's benefits, but now shut out of government monopolies." 5

Yet exactly how the provisions of the federal Cannabis Act, which came into force on 17 October 2018, will apply to Indigenous communities has not been addressed in the legislation, which vests control over the implementation of the law and its regulations in the federal and provincial governments only. ${ }^{6}$ This omission has sparked outcry on the part of Indigenous peoples across Canada, who have also expressed concern over the lack of adequate consultation by the government, the application of provincial regulations on reserves and traditional territories, and the exclusion of First Nations from the law's excise tax revenue sharing framework, among other issues. ${ }^{7}$

In this respect, the new legislation sits uneasily with another significant aspect of Trudeau's campaign platform — his promise of a "renewed relationship with Indigenous peoples," including the establishment of a new "nation-to-nation" relationship, the implementation of the United Nations Declaration on the Rights of Indigenous Peoples, ${ }^{8}$ and the enactment of the Calls to Action of the Truth and Reconciliation Commission (TRC). ${ }^{9}$ Several of these Calls to Action are highly relevant in the context of cannabis legalization, including recommendations concerning economic development, ${ }^{10}$ criminal justice, ${ }^{11}$ the reaffirmation of the nation-to-nation relationship between Aboriginal peoples and the Crown, ${ }^{12}$ and the full adoption and implementation of UNDRIP as a framework for reconciliation. ${ }^{13} U N D R I P$, in turn, enshrines a number of rights that have bearing on cannabis

The term "Cannabis" refers to the genus of flowering plants in the family Cannabaceae, and includes Cannabis sativa and Cannabis indica. "Marijuana" is still frequently used to refer to the cannabis plant - particularly its drug preparations - although there is an increasing movement away from this name due to its racist roots in the US prohibition movement. See Alex Halperin, "Marijuana: Is it Time to Stop Using a Word with Racist Roots?" The Guardian (29 January 2018), online: <https://www.theguardian. com/society/2018/jan/29/marijuana-name-cannabis-racism>. Liberal Party of Canada, Real Change: A New Plan for a Strong Middle Class (2015) at 55, online: $<$ https://www.liberal.ca/wp-content/uploads/2015/10/New-plan-for-a-strong-middle-class.pdf $>$. ICC, "Mohawk Territory Makes History," supra note 2.

Cannabis Act, SC 2018, c 16, enacted by Bill C-45, An Act respecting cannabis and to amend the Controlled Drugs and Substances Act, the Criminal Code and other Acts, 1st Sess, 42nd Parl, 20152016-2017-2018 (assented to 21 June 2018) [Bill C-45]. Jorge Barrera, "Assembly of First Nations Wants Provinces, Territories to Butt Out of First Nations Pot Sales," CBC News (2 May 2018), online: <www.cbc.ca/news/indigenous/assembly-first-nationsprovinces-marijuana-sales-1.4645525>. United Nations Declaration on the Rights of Indigenous Peoples, GA Res 61/295, UNGAOR, 61st Sess, Sup No 53, UN Doc A/61/295 (2007), online: <www.un.org/esa/socdev/unpfii/documents/DRIPS en.pdf $>$ [UNDRIP].

$9 \quad$ Liberal Party of Canada, supra note 4 at $46-48$.

10 Truth and Reconciliation Commission of Canada: Calls to Action (Winnipeg: TRC, 2015) at Recommendations 7, 92(ii), online: <trc.ca/assets/pdf/Calls_to_Action_English2.pdf > [TRC, Calls to Action].

Ibid at Recommendations 30, 38 .

Ibid at Recommendation 45

Ibid at Recommendations 43-44. 
legalization, including rights concerning political and economic self-determination, traditional knowledge, and cultural practices. ${ }^{14}$

Yet in spite of the tremendous opportunities presented by cannabis legalization, the federal government's proposed framework fails on nearly every count. Examining cannabis in Canada through the lens of reconciliation and the rights of First Nations, Métis, and Inuit peoples thus reveals both the potential of legalization for Indigenous communities, as well as the very real risk that the new legal framework will simply perpetuate existing injustices.

To some extent, issues raised in the Canadian context also mirror some of the injustices and shortcomings of existing legal frameworks governing cannabis and Indigenous peoples' rights at the international level, where complex and interconnected histories of prohibition, colonialism, and imperialism continue to affect the protection of genetic resources and traditional knowledge. As cannabis cultivation moves from the black market to a multibillion dollar legal industry, the role that Indigenous and local communities have played in the cultivation and protection of cannabis genetic resources and related traditional knowledge has not been adequately addressed.

This article seeks to examine the intersections between Canadian cannabis legalization, reconciliation, and the rights of Indigenous peoples. Part II will begin with a brief overview of the use of cannabis in cultures around the world, as well as international efforts to prohibit its cultivation, use, and trade. Drawing on insights from historical geography, sociology, and biopolitics, it will examine how the ways in which the cannabis plant has been defined, classified, and regulated under international law sit uneasily with other legal frameworks, including those governing the rights of Indigenous peoples and the protection of plant genetic resources and associated traditional knowledge. Part III will then turn to the history and status of cannabis in Canada, tracing legal developments from prohibition to gradual regulation for medical and recreational use. Finally, Part IV will examine the new landscape of cannabis legalization through the lens of the Truth and Reconciliation Commission's recommendations and the rights of First Nations, Métis, and Inuit peoples in Canada.

\section{Contingent Definitions of CANnAbis AND THE IMPLICATIONS FOR INDIGENOUS AND LOCAL COMMUNITIES OF CANNABIS REGULATION UNDER INTERNATIONAL LAW}

Human use of cannabis dates back at least 12,000 years. ${ }^{15}$ Amongst the oldest cultivated crops in human history, the plant likely originated in Central Asia. ${ }^{16}$ In the intervening millennia, cannabis cultivation spread across East and South Asia, Europe, the Middle East, at 419 [Warf, "High Points"]; Matthew T Welling et al, "A Belated Green Revolution for Cannabis: Virtual Genetic Resources to Fast-Track Cultivar Development" (2016) 7 Frontiers in Plant Science at 6. Dennis J Gray, Robert C Clarke, and Robert N Trigiano point out that the "hemp" and "drug" varieties of the species Cannabis sativa L. were domesticated at different points in history; the earliest records for the domestication of cannabis as a fiber crop date from $8500 \mathrm{BP}$, while drug forms of cannabis were domesticated by 3000 BP ("Introduction to the Special Issue on Cannabis" (2016) 35:5-6 Critical Reviews in Plant Sciences 289 at 289). 
Africa, and the Americas. ${ }^{17}$ Throughout the long history of its cultivation, cannabis was valued for its psychoactive and non-psychoactive properties alike - widely used for its fibers (usually referred to as hemp), as a food, and for a wide range of ceremonial, recreational, therapeutic, and medicinal applications across cultures. ${ }^{18}$

In the modern period, the history of cannabis became intertwined with the processes of colonialism and the industrial revolution, as "drug plants that once had meanings and uses associated with particular peoples and places were re-made as novel, exotic commodities for consumption by others elsewhere." 19 Substances ranging from tea and tobacco to opium and coca played a significant role in European economic expansion. ${ }^{20}$ Bradburd and Jankowiak in particular draw out the linkages between drugs, trade, and labour, emphasizing the way in which "[t]he introduction of drugs was a significant and deliberate technique for the capture of labor and commodities in market expansion" — used as both "a tool of seduction, inducing people to provide goods or labor," as well as "a way of increasing the intensity or duration of labor." 21 The regulation of cannabis was used by colonial powers to achieve similar ends, ${ }^{22}$ and its taxation also provided a source of imperial income. ${ }^{23}$

Viewed in this light, the uneven history of cannabis prohibition has much less to do with any scientific assessment of the drug and its effects than it does "with broader understandings of power, knowledge, class, ethnicity, and the state." ${ }^{24}$ In this way:

Cannabis has long been entwined with the world economy and local social and cultural practices in a variety of ways; its historical geography, therefore, points to the intersections between broad social relations that give the plant's use some degree of consistency (especially religious and shamanistic applications) and the contingent specifics of individual societies and places. ${ }^{25}$

This entwinement has impacted both the way in which cannabis has been characterized and defined by law - as an illicit drug, an agricultural product, a genetic resource, a medicine, or a sacrament - as well as who has the power to make such characterizations. Current moves to legalize marijuana in countries such as Canada must therefore be understood as arising from this context; as a regulated substance, even within the most seemingly liberal frameworks, cannabis remains a site of contested meaning, knowledge, and power.

For an excellent overview of the historical geography of cannabis, see ibid at 418-25. See also Ethan B Russo, "History of Cannabis and its Preparations in Saga, Science, and Sobriquet" (2007) 4 Chemistry \& Biodiversity 1614; Michael Aldrich, "History of Therapeutic Cannabis" in Mary Lynn Mathre, ed, Cannabis in Medical Practice: A Legal, Historical and Pharmacological Overview of the Therapeutic Use of Marijuana (Jefferson: McFarland \& Company, 1997) 35.

19 Stewart Williams \& Barney Warf, "Drugs, Law, People, Place and the State: Ongoing Regulation, Resistance and Change" (2016) 20:1 Space \& Polity 1 at 1.

Daniel Bradburd \& William Jankowiak, "Drugs, Desire, and European Economic Expansion" in William Jankowiak \& Daniel Bradburd, eds, Drugs, Labor, and Colonial Expansion (Tuscon: University of Arizona Press, 2003) 3 at 3. See also Warf, "High Points," supra note 15 at 428. .

Chris S Duvall, "Drug Laws, Bioprospecting and the Agricultural Heritage of Cannabis in Africa" (2016) 20:1 Space \& Polity 10 at 15; Warf, "High Points," supra note 15 at 428.

Warf, "High Points," ibid at 427.

Ibid at 418 .

Ibid at 415 . 
In the case of Indigenous and local communities, the treatment of cannabis under international law illustrates how dominant interests have been able to define cannabis in ways that largely obscure and negate the role that these communities have played in the cultivation and protection of cannabis strains over many generations, along with the immense bodies of knowledge they have developed, stewarded, and imparted. Many Indigenous societies have coevolved with psychoactive plants, including cannabis ${ }^{26}$ and the present-day diversity of cannabis landraces is the result of human selection practices "embedded in indigenous knowledge systems." ${ }^{27}$ Yet these contributions have generally been minimized. In the African context, Duvall has pointed out how colonial laws defined cannabis narrowly as a "one-dimensional drug crop," failing to recognize or value its "non-psychoactive, indigenous uses. $" 28$ This definition resulted in particularly strict controls on the plant and its complete exclusion from agricultural research and development. ${ }^{29}$

In spite of prohibition, bioprospectors have sought out and relied upon the genetic diversity of cannabis landraces, which embody the traditional knowledge and labour of the Indigenous and local communities that have cultivated them over generations. Beginning in the 1960s, seed collectors set out along the Hippie Trail seeking "to recover and investigate endemic cannabis strains." 30 There is now "a second wave of interest in these indigenous strains of cannabis," as strain hunters once again travel the world in search of landraces. ${ }^{31}$ In part, the importance and value of these landraces lies in their genetic diversity, which is much greater than that of many modern hybrid strains. ${ }^{32}$

As certain national and subnational jurisdictions move to legalize recreational cannabis, the stakes for these bioprospectors are high; the value of the global legal cannabis industry is projected to reach $\$ 31.4$ billion by $2021 .{ }^{33}$ Yet the benefits derived from these genetic resources and associated traditional knowledge are not being realized by the Indigenous and local communities themselves. As Duvall points out in the African context, global drug laws have resulted in a situation where cannabis "is simultaneously illegal and a valuable stock of crop genetic diversity." 34

Michael K Steinberg, "Introduction” in Michael K Steinberg, Joseph J Hobbs \& Kent Mathewson, eds, Dangerous Harvest: Drug Plants and the Transformation of Indigenous Landscapes (Oxford: Oxford University Press, 2004) 3 at 3.

27 Duvall, supra note 22 at 14, 11-12. The term "landrace" refers to a "locally adapted and distinctive population of a cultivated plant that lacks formal improvement" (ibid at 12).

Ibid at 16 .

Ibid at 19.

Amanda Feilding, "Jamaican Cannabis Landraces: History and Importance," Huffpost (16 February 2016), online: Huffington Post $<$ https://www.huffingtonpost.com/amanda-feilding/jamaican-cannabislandrac b 9110156 .html $>$.

Ibid.

Ibid; Michael Pollan, The Botany of Desire: A Plant's-Eye View of the World (New York: Random House, 2001) at 128 .

33 Mona Zhang, "The Global Marijuana Market Will Soon Hit \$31.4 Billion But Investors Should Be Cautious," Forbes (7 November 2017), online: <https://www.forbes.com/sites/monazhang/2017/11/07/ global-marijuana-market-31-billion-investors-cautious/\#6d3e1c972977>.

Duvall, supra note 22 at 11 . 
In addition to the international drug conventions that regulate cannabis as an illicit substance, ${ }^{35}$ other international legal frameworks are also ill-suited to protect communities' genetic resources and associated traditional knowledge, and may actually reinforce and perpetuate injustices in this regard. For example, the international regime concerning the protection of plant genetic resources under the International Convention for the Protection of New Varieties of Plants provides a sui generis form of intellectual property protection specifically adapted to the process of plant breeding, and was the first formal agreement to regulate plant genetic resources at the international level. ${ }^{36}$ However, the Convention "rest[s] on a distinction between 'raw' and 'worked' [plant genetic resources] in which only the latter are eligible for protection." ${ }^{37}$ It thus only confers protection for commercial plant varieties that are deemed to be new, distinct, uniform, and stable. ${ }^{38}$ This means that both underground breeders and traditional knowledge holders are effectively legislated out of the Plant Breeders' Rights protection regime.

In the case of underground marijuana breeders, prohibition has meant that they could not apply for protection for illicit plant varieties, and given the plant's illegal status, few if any records have been kept to sufficiently prove the selection process and connection between themselves and a particular variety. Examples of the kind of anecdotal evidence used to try and attribute strains to particular breeders illustrate these difficulties:

The battle over who actually invented the strain has turned into a political struggle, dividing the public into two camps. Some believe that the White Widow was discovered by a man named Ingemar, while others take the side of another skillful breeder known as Shantibaba. ${ }^{39}$

According to the most credible source; Northern Lights was originally bred by a man known as "The Indian" on an Island near Seattle Washington in the United States. Some also claim that the plant originated in California before ending up in the hand of this mysterious man from Seattle but there is no conclusive evidence to support this. 40

According to the most reliable story, written by Jesse for the Treat Yourself Magazine, this plant was apparently liberated by an unknown assistant from a government research facility at the University of Mississippi. The G13 was part of a project run by a Dr. Carlton Turner, who was conducting research on both cannabis sativa and cannabis indica drug strains. One thing is known for a fact and that is that Neville Schoenmakers, who also founded the Seed Bank, got a hold of a clone marked G13 some way or the other.

As an illicit drug, access to marijuana is controlled at the international level via three international treaties: Single Convention on Narcotic Drugs, 1961,30 March 1961, 520 UNTS 151 (entered into force 13 December 1964); Convention on Psychotropic Substances, 21 February 1971, 1019 UNTS 175 (entered into force 16 August 1976); United Nations Convention Against Illicit Traffic in Narcotic Drugs and Psychotropic Substances, 20 December 1988, 1582 UNTS 95 (entered into force 11 November 1990).

36 International Convention for the Protection of New Varieties of Plants, 2 December 1961, 815 UNTS 89 (entered into force 24 April 1968) [UPOV Convention].

37 Carolina Roa-Rodríguez \& Thom Van Dooren, "Shifting Common Spaces of Plant Genetic Resources in the International Regulation of Property" (2008) 11:3 J World Intellectual Property 176 at 185. UPOV Convention, supra note 36, arts 5-9.

39 "The Origins of the White Widow Cannabis Strain" (20 March 2014), Seedsman (blog), online: $<$ https://blog.seedsman.com/the-origins-of-white-widow-marijuana-strain/>.

40 "The Origins of Northern Lights Cannabis Strain" (20 March 2014), Seedsman (blog), online: $<$ https://blog.seedsman.com/the-origins-of-northern-lights-cannabis-strain/>. 
Opinions vary but apparently it was given to him by man called Sandy Weinstein, who had a friend working at the government research facility in Mississippi.

Another story points towards a man named Michael Hallman, who had acquired a lot of cannabis strains during the 1960's and 1970's. Following his arrest, these strains ended up in the possession of the CIA and FBI and were later used to genetically engineer the notorious G13 cannabis strain in secret government labs. ${ }^{41}$

Nor would traditional knowledge holders qualify under the requirements of this regime, as the products of their breeding are unlikely to meet the criteria of distinctness, uniformity, and stability required for plant variety protection. For the most part, their breeding and cultivation practices do not produce uniform plants generation after generation; rather, the strength of the landraces they have cultivated lies in their diversity. Moreover, the private intellectual property rights offered under the UPOV Convention may be at odds with the collective nature of plant breeding in farming communities. ${ }^{42}$

Yet the history of strain hunters and Hippie Trail bioprospectors shows that genetic material was obtained from Indigenous and local communities for use by breeders in the West, and knowledge holders from these communities provided useful information concerning the properties of different varieties, significantly reducing the cross-breeding efforts needed to arrive at particular traits. Moreover, it is safe to assume that in the past there has been little, if any, in the way of benefit sharing with these communities. This problem persists today, as multinational seed companies collect genetic wealth without sharing the benefits with farmers and cultivators. ${ }^{43}$ As Duvall notes in the African context, such companies "use African germplasm in sophisticated breeding programmes, yet acknowledge no [intellectual property rights] for African farmers and offer no obvious benefits to them."

Other international frameworks offer somewhat more promise for the protection of genetic resources and associated traditional knowledge. The Nagoya Protocol on Access to Genetic Resources and the Fair and Equitable Sharing of Benefits Arising from their Utilization to the Convention on Biological Diversity ${ }^{45}$ aims to ensure that the benefits arising from the utilization of genetic resources are shared in a fair and equitable way. It sets out obligations to seek the prior informed consent of Indigenous and local communities for access to the traditional knowledge associated with genetic resources held by such communities as well as those genetic resources themselves in cases where the rights of Indigenous and local communities over the resources have been recognized. ${ }^{46}$ The Protocol also provides for the sharing of benefits arising from the use of genetic resources and associated traditional knowledge. This benefit sharing must be based on mutually agreed terms. ${ }^{47}$

"The Origins of G13 Cannabis Strain" (20 March 2014), Seedsman (blog), online: <https:// blog.seedsman.com/the-origins-of-g13-cannabis-strain/>.

Rene Salazar, Niels P Louwaars \& Bert Visser, "Protecting Farmers' New Varieties: New Approaches to Rights on Collective Innovations in Plant Genetic Resources" (2006) 35:9 World Development 1515 at $1520-21$.

Duvall, supra note 22 at 11.

Ibid.

29 October 2010 (entered into force 12 October 2014), online: <https://www.cbd.int/traditional/ Protocol.shtml $>$ [Nagoya Protocol]. This is a supplementary agreement to the Convention on Biological Diversity, 5 June 1992, 1760 UNTS 79 (entered into force 29 December 1993).

Nagoya Protocol, ibid, arts 6-7.

Ibid, art 5. 
The United Nations Declaration on the Rights of Indigenous Peoples ${ }^{48}$ also contains important provisions on the requirement of free, prior, and informed consent of Indigenous peoples. Under UNDRIP, Indigenous peoples have the right to maintain, control, protect, and develop their traditional knowledge and intellectual property, as well as their genetic resources, seeds, medicines, and knowledge of the properties of fauna and flora. ${ }^{49}$ States are also required to provide redress (and in some cases restitution or compensation) in cases where Indigenous peoples' cultural, intellectual, religious, and spiritual property is taken without their free, prior, and informed consent or in violation of their laws, traditions, and customs. ${ }^{50}$

However, much of the acquisition of genetic resources and knowledge from Indigenous communities occurred before current legal instruments for protection were in place, and thus in many cases without free, prior, and informed consent and without any provisions for benefit sharing. In addition, as is the case with the UPOV Convention, the prohibited nature of cannabis production has contributed to difficulties in proving that knowledge or resources were taken without consent.

All in all, as Williams and Warf note, "the multifaceted phenomenon of drugs, ranging across drug production, distribution and consumption, and thereby implicating many, different peoples, places and practices, cannot be understood without paying attention to their legal status. ${ }^{.51}$ The legal categorization of a substance as a drug or otherwise - and the crucial question of who has the power to make such categorizations in the first place - must also be considered as an aspect of Indigenous self-determination according to the principles enshrined in UNDRIP, and in the context of cannabis legalization in Canada.

\section{The USE AND REgUlation OF CANNABIS IN THE CANAdian CONTEXT}

There is uncertainty in the scientific community as to the history of the cannabis plant in North America. While some suggest that cannabis arrived in the Americas through European contact beginning in the sixteenth century ${ }^{52}$ there is also evidence indicating that cannabis may have been used in the Americas in the pre-Columbian era. ${ }^{53}$ Traces of hemp have been found in resin scrapings of 500-year-old pipes in Morriston, Ontario, and hemp fiber pouches from around $800 \mathrm{AD}$ have been discovered in the Ohio Valley. ${ }^{54}$ Spicer notes that "[e]lders of some North American native tribes can also remember their ancestors using cannabis in a ritual manner." ${ }^{55}$ The National Indigenous Medical Cannabis Association has stated that cannabis "was used widely by various Indigenous or First Nation tribes thousands of years

UNDRIP, supra note 8.

Ibid, art 31(1).

Ibid, arts 11(2), 28(1), 32.

Williams \& Warf, supra note 19 at 8.

Warf, "High Points," supra note 15 at 425; Antonio Waldo Zuardi, "History of Cannabis as a Medicine: A Review" (2006) 28:2 Brazilian J Psychiatry 153 at 155

John L Sorenson \& Carl L Johannessen, "Scientific Evidence for Pre-Columbian Transoceanic Voyages" (2004) 133 Sino-Platonic Papers 1 at 11; Leah Spicer, "Historical and Cultural Uses of Cannabis and the Canadian "Marijuana Clash,"” prepared for the Senate Special Committee on Illegal Drugs (12 April 2002), online: <https://sencanada.ca/content/sen/committee/371/ille/library/spicere.htm>.

54 Spicer, ibid.

Ibid. 
before colonization of what we refer to as Turtle Island," stating that there have been "countless academic studies, archeological findings and reports, archive research and a plethora of journal entries from early European explorers which all corroborates that Indigenous peoples were using cannabis and hemp in its various forms long before any settlers came to North America." ${ }^{, 56}$ Carol Hopkins, a member of the Delaware First Nation in Moraviantown, Ontario and Executive Director of the Thunderbird Partnership Foundation, has also stated that "the cannabis plant has been sited throughout history of First Nation culture," noting that "[t]here are Elders and cultural practitioners who speak about the use of cannabis in health and ceremony.... A topical medicine is one of the ways cannabinoids have been used; it is applied on the skin to reduce pain." ${ }^{, 57}$

For much of the eighteenth and nineteenth centuries, the cannabis plant was grown for hemp throughout the colonies, and was also widely used in medicinal practice. ${ }^{58}$ Beginning in the early twentieth century, however, "anti-marijuana fervor" swept the United States, spurred on in large part by racial antipathy. ${ }^{59}$ Marijuana prohibition in Canada was also motivated in part by racist attitudes, including "by the apparent connection between psychoactive drugs and Chinese-Canadian culture. "60 For example, Stoa notes that "[p]rior to 1908 , Canadians were free to purchase commercially available drugs such as opium and cocaine. But the rancor between white and Chinese Canadians prompted a backlash against these and other drugs, and legislation quickly followed suit between $1908-1920 .{ }^{\circ 61}$ With the adoption of the Opium Act ${ }^{62}$ of 1908, which made it an offence to import, manufacture, possess, or sell opium, Canada positioned itself at the forefront of international drug prohibition. $^{63}$

Cannabis joined the ranks of prohibited substances in 1923, when it was added as a restricted drug under the Opium and Narcotic Drug Act. ${ }^{64}$ In 1938, the commercial

56 "National Indigenous Medical Cannabis Association (NIMCA) Position Statement — Indigenous People, Cannabis and Bill C-45," online: $<$ https://www.ourcommons.ca/Content/Committee/421/HESA/ Brief/BR9074826/br-external/NationalIndigenousMedicalCannabisAssociation-e.pdf $>$.

57 Lynne Brown, "Anishinabek Health Conference Hosts Cannabis Conversation with Carol Hopkins," Anishinabek News (8 February 2017), online: <anishinabeknews.ca/2017/02/08/anishinabek-healthconference-hosts-cannabis-conversation-with-carol-hopkins/>.

58 Spicer, supra note 53.

59 Ryan B Stoa, "Comparative Cannabis: Approaches to Marijuana Agriculture Regulation in the United States and Canada" (2017) 49 U Pacific L Rev 89 at 98; Warf, "High Points,"supra note 15 at 429.

60 Stoa, ibid. For example, Catherine Carstairs notes that "[i]deas about the morally-degenerate but highly intelligent and cunning Chinese, played a key role in anti-drug discourse in Canada" ('Hop Heads' and 'Hypes': Drug Use, Regulation and Resistance in Canada, 1920-1961 (PhD Thesis, University of Toronto, 2000) [unpublished] at 15, online: <www.collectionscanada.gc.ca/obj/s4/f2/dsk2/ftp03/NQ 53757.pdf $>$ ).

Stoa, ibid [footnotes omitted].

SC 1908 , c 50.

Dan Malleck, When Good Drugs Go Bad: Opium, Medicine, and the Origins of Canada's Drug Laws (Vancouver: UBC Press, 2015) at 5.

64 SC 1923, c 22, as amended. See Canada, Legal and Social Affairs Division Parliamentary Information and Research Service, "The Legal Regulation of Marijuana in Canada and Selected Other Countries," by Robin MacKay \& Karin Phillips, Publication No 2106-94-E (Ottawa: Library of Parliament, 2016) at 6 . The reasons behind this prohibition in 1923 remain unclear, and cannabis was added to the schedule of restricted drugs without debate. See Daniel Schwartz, "Marijuana was Criminalized in 1923, But Why?" CBC News (3 May 2014), online: <https://www.cbc.ca/news/health/marijuana-was-criminalizedin-1923-but-why-1.2630436>. See also Catherine Carstairs, Jailed for Possession: Illegal Drug Use, Regulation, and Power in Canada, 1920-1961 (Toronto: University of Toronto Press, 2006); PJ Giffen, Shirley Endicott \& Sylvia Lambert, Panic and Indifference: The Politics of Canada's Drug Laws: A Study in the Sociology of Law (Ottawa: Canadian Centre on Substance Abuse, 1991). 
cultivation of industrial hemp was also banned. ${ }^{65}$ Stoa notes that "Canadian marijuana cultivation, use, and prosecution remained relatively dormant until the 1960s, when both consumption and prosecutions increased exponentially." ${ }^{\text {"T6 }}$ The government responded by enacting the Narcotic Control Act of 1961, which increased penalties and enabled prosecutions ${ }^{67}$ Controversy over the prohibition of marijuana resulted in a federal inquiry into marijuana policy reform, culminating in the Le Dain Commission Report of 1972, which recommended that cannabis prohibition be repealed for personal cultivation and use. ${ }^{68}$ This recommendation was not adopted, however, and cannabis remained a prohibited substance in Canada until the end of the twentieth century. ${ }^{69}$

The first steps toward the legalization of cannabis in Canada for medical purposes began as early as 1999, when the first two individuals received authorization to use cannabis as medicine. $^{70}$ The following year, the Ontario Court of Appeal in R. v. Parker found that the prohibition of marijuana was unconstitutional because it did not allow for any type of medical use. ${ }^{71}$ In 2003 , the same court stated in R. v. P.(J.) that

\footnotetext{
the [Marihuana Medical Access Regulations] did not create a constitutionally acceptable medical exemption. In Parker, this court made it clear that the criminal prohibition against possession of marihuana, absent a constitutionally acceptable medical exemption, was of no force and effect. As of April 12, 2002, there was no constitutionally acceptable medical exemption. It follows that as of that date the offence of possession of marihuana in s. 4 of the [Controlled Drugs and Substances Act] was of no force and effect. ${ }^{72}$
}

In 2001, the Canadian Marihuana Medical Access Regulations ${ }^{73}$ granted legal access to marijuana for those suffering from HIV, AIDS, and other illnesses. Authorized patients could purchase marijuana from Health Canada, grow it for themselves, or designate a third party to grow it for them. By 2014, the 100 or so patients authorized to access medical marijuana in 2001 had grown to over $37,000 .{ }^{74}$ Citing concerns over home grow operations and abuse of the system, the federal government announced in 2013 that the MMAR would be replaced by the Marihuana for Medical Purposes Regulations. ${ }^{75}$ Under the MMPR, qualified patients were not permitted to grow their own cannabis; legal medical marijuana could only be obtained through companies authorized by Health Canada, referred to as Licensed Producers. ${ }^{76}$ The $M M P R$ thus essentially privatized the provision of marijuana for medical

$65 \quad$ Spicer, supra note 53.

$66 \quad$ Stoa, supra note 59 at 98.

Narcotic Control Act, SC 1961, c 35. See Stoa, ibid.

68 Stoa, ibid at 99.

69 Carolynn Conron, “Canada’s Marijuana Medical Access Regulations: Up in Smoke” (2013) 6 Albany Government L Rev 259 at 261-65.

70 The Canadian Press, "A Timeline of Some Significant Events in the History of Marijuana in Canada," The Canadian Press (2014), online: <cponline.thecanadianpress.com/graphics/2014/medical-marijuanatimeline/>.

$R v$ Parker (2000), 49 OR (3d) 481 (CA).

$R v(P) J(2003), 67$ OR (3d) 321 at para $11(\mathrm{CA})$.

SOR/2001-227 [MMAR], as repealed by Marihuana for Medical Purposes Regulations, SOR/2013-119, s $267[M M P R]$.

"Feds Defend New Medical Marijuana Laws as Public Safety Issue," CBC News (3 March 2014), online: $<$ https://www.cbc.ca/news/canada/british-columbia/feds-defend-new-medical-marijuana-laws-as-publicsafety-issue-1.2558463>.

75 MMPR, supra note 73, as repealed by Access to Cannabis for Medical Purposes Regulations, SOR/2016-230, s 281.

76 Government of Canada, "Getting Cannabis From a Licensed Producer," online: < https://www. canada.ca/en/health-canada/services/getting-cannabis-from-licensed-producer.html $>$. 
purposes. In addition, the new Regulations only authorized users to purchase dried marijuana, meaning that alternative methods of preparation such as teas or baked goods could prompt criminal trafficking and narcotics possession charges under the Controlled Drugs and Substances Act. ${ }^{77}$

The new rules under the MMPR spurred litigation. In 2015, the Supreme Court of Canada in $R$. v. Smith struck down some of the restrictions imposed by the $M M P R$, ruling that authorized medical marijuana patients were entitled to consume cannabis in various forms, including edible and topical forms, rather than simply smoking or vaporizing it. ${ }^{78}$ The Federal Court in Allard v. Canada went a step further. The applicants in that case launched a constitutional challenge of the $M M P R$, arguing that the provisions prohibiting authorized patients from growing their own cannabis blocked their access to affordable medicine. ${ }^{79}$ The Court agreed, pronouncing the $M M P R$ invalid on the grounds that it unjustifiably infringed liberty and security interests pursuant to section 7 of the Charter of Rights and Freedoms, and ruling that Canadians thus have a constitutional right to grow their own marijuana for medical purposes. ${ }^{80}$

In response to the decision, the government reiterated its plans to move forward with the legalization of marijuana for recreational use - one of the Liberal Party's key promises during the 2015 federal election. ${ }^{81}$ Following their election win, the Liberal government assembled a Task Force on Cannabis Legalization and Regulation in June 2016 with a mandate to consult and provide advice on the design of a new legislative and regulatory framework for legal access to cannabis. ${ }^{82}$ The Task Force released a final report in December 2016, which provided a number of non-binding recommendations for consideration by federal and provincial governments. ${ }^{83}$ Bill C-45 was subsequently introduced to Parliament in 2017; it received Royal Assent on 21 June 2018, and came into force on 17 October 2018 as the Cannabis Act. ${ }^{84}$

The Cannabis Act, in conjunction with An Act to amend the Criminal Code (offences relating to conveyances) and to make consequential amendments to other Acts) (Bill C-46), ${ }^{85}$ provides for the nationwide legalization and regulation of cannabis. Under the provisions of the Cannabis Act, adults who are 18 or older (depending on the province or territory) are legally permitted to possess up to 30 grams of legal cannabis (dried or equivalent in nondried form) in public; to share up to 30 grams with other adults; to purchase cannabis products from a provincial or territorial retailer; and to grow up to four plants per residence

\footnotetext{
SC 1996, c 19.

$R v$ Smith, 2015 SCC 34 at paras 1-2.

Allard v Canada, 2016 FC 236.

Ibid.

While campaigning for the federal election, Liberal Party leader Justin Trudeau promised to "legalize, regulate, and restrict access to marijuana" (Liberal Party of Canada, "Marijuana," online: $<\mathrm{https}: / / \mathrm{www}$. liberal.ca/realchange/marijuana/ $>$ ).

Government of Canada, A Framework for the Legalization and Regulation of Cannabis in Canada: The Final Report of the Taskforce on Cannabis Legalization and Regulation (Ottawa: Health Canada, 30 November 2016) at 2, online: < healthycanadians.gc.ca/task-force-marijuana-groupe-etude/frameworkcadre/alt/framework-cadre-eng.pdf $>$.

Ibid.

Supra note 6.

Bill C-46, 1st Sess, 42nd Parl, 2018 (assented to 21 June 2018), SC 2018, c 21.
} 
for personal use from licensed seeds or seedlings. ${ }^{86}$ Jurisdiction for the Act's implementation is split between the federal, provincial, and territorial governments, giving the provinces and territories the authority within their jurisdiction to increase the minimum age requirement, lower the personal possession limit, create additional rules for growing cannabis at home, and restrict where adults can consume cannabis. However, the Act is silent with respect to its application to First Nations and other Indigenous communities, suggesting, in the absence of any dispensation to the contrary, that the federal, provincial, and territorial governments intend to regulate marijuana sales on-reserve.

\section{Cannabis Legalization, Reconciliation, AND THE RightS OF INDIGENOUS PEOPLES IN CANADA}

First Nations, Métis, and Inuit people across Canada are incredibly diverse, and as such, hold a wide variety of views on cannabis and its place in Indigenous culture. ${ }^{87}$ Some see the relationship between cannabis and Indigenous communities in positive terms. For example, the website of the Indigenous Cannabis Cup notes:

Indigenous people have long had an affinity to cannabis, and have been inhaling a wide variety of dried plant matter for spiritual, medicinal, and "recreational" reasons since time immemorial. Indigenous people treated the cannabis plant no differently than any other part of creation, and in many ways, they were innovators in the use of cannabis. ${ }^{88}$

Others have expressed concerns about the social implications of cannabis legalization, worrying that marijuana could prove to be as destructive as alcohol in Indigenous communities. $^{89}$

But while opinions may differ on the role of cannabis in First Nations, Métis, and Inuit communities, it is clear that Indigenous peoples in Canada have been disproportionately affected by cannabis prohibition. While research has shown that cannabis use across racial groups is similar, Indigenous people in Canada are overrepresented in cannabis possession arrests across the country. ${ }^{90}$ For example, in the city of Regina, Indigenous people were nearly nine times more likely to be arrested for cannabis possession than white people over

86 See Government of Canada, "Cannabis in Canada: Get the Facts" (28 February 2019), online: <https:// www.canada.ca/en/services/health/campaigns/cannabis/canadians.html>.

87 Lenard Monkman, "Is There a Place for Cannabis in First Nations Culture?" CBC News (12 January 2018), online: <www.cbc.ca/news/indigenous/is-there-a-place-for-cannabis-in-first-nations-culture$1.4485865>$.

Supra note 1.

"Dene Nation Calls on Feds to Postpone Legalizing Cannabis for at Least 2 Years," CBC News (30 May 2018), online: $<$ www.cbc.ca/news/canada/north/dene-nation-opposes-legal-cannabis-1.4684692> [CBC, "Dene Nation Calls on Feds"].

90 Rachel Browne, "Black and Indigenous People Are Overrepresented in Canada's Weed Arrests," VICE News (18 April 2018), online: <https://news.vice.com/en_ca/article/d35eyq/black-and-indigenouspeople-are-overrepresented-in-canadas-weed-arrests $>$. In order to obtain this information,

VICE News submitted freedom of information requests to 14 police services across Canada for single-charge cannabis possession arrest statistics from 2015 to 2017 broken down by race, age, gender of the accused, and other categories. Data related to the offence of cannabis possession was requested because it will be legal to possess up to 30 grams of cannabis after legalization, and because of the wide discretion police have in arresting and charging people for this offence.... These datasets were shared with University of Toronto criminologists Akwasi OwusuBempah and Alex Luscombe who reviewed them and provided analysis. 
the period from 2015 to $2017 . .^{91}$ Although there are significant gaps in racially disaggregated data on arrests, charges, and custodial sentences in Canada, the prohibition of cannabis is widely understood as a significant factor in the over-incarceration of Indigenous people in the country. ${ }^{92}$ Indigenous people make up 4.3 percent of the total Canadian population, but they comprise 23 percent of federal inmates, ${ }^{93}$ and minor cannabis possession offences are regarded by many as a gateway to the criminal justice system. ${ }^{94}$

The "distinct histories of colonization and cultural oppression" experienced by First Nations, Inuit, and Métis peoples in Canada have also given rise to "substantial burdens of social and health inequalities ... connected to a high burden of drug-related harms and drugrelated structural violence, including over-representation in the criminal justice system for drug offences." 95 Thus, in addition to being disproportionately targeted in relation to prohibition, Indigenous peoples in Canada have carried a far greater share of the social and health burdens connected to drug policies, stemming in large part from historical and ongoing injustices.

Prohibition of cannabis in Canada has also impacted the plant's economic role in Indigenous communities. The website of the Indigenous Cannabis Cup states that in spite of nearly 100 years of cannabis criminalization, "indigenous involvement in the cannabis industry has remained consistent" and "countless numbers of indigenous people have sustained themselves and their families by growing and selling cannabis," noting that "[a]fter tobacco, cannabis is likely the second greatest form of private employment in Indian country." $" 96$ The economic aspects of cannabis are closely linked to issues of sovereignty and self-determination, as a number of First Nations communities seek to regulate on-reserve marijuana sales on their own terms, without interference from the provincial or federal governments. $^{97}$

The continuing injustices of cannabis prohibition faced by Indigenous communities, and the questions of political and economic self-determination highlighted by legalization, lie at the very heart of reconciliation, and are reflected in spirit and in letter in a number of the Calls to Action of the Truth and Reconciliation Commission of Canada (TRC). Established

$91 \quad$ Ibid.

92 Evan Soloman, “A Bad Trip: Legalizing Pot Is About Race,” Maclean's (14 April 2017), online: $<$ https://www.macleans.ca/politics/ottawa/a-bad-trip-legalizing-pot-is-about-race/>.

Ibid.

Akwasi Owusu-Bempah, "Cannabis Legalization and Equity in Canada" (18 December 2017), Broadbent Institute (blog), online: <www.broadbentinstitute.ca/aobempah/cannabis_legalization_and equity in canada>; "Convicted Pot Offenders Need Special Access to the Legal Weed Market: Sociologist," The Current (12 February 2018), online: CBC Radio <www.cbc.ca/radio/thecurrent/thecurrent-for-february-12-2018-1.4529256/convicted-pot-offenders-need-special-access-to-the-legalweed-market-sociologist-1.4531948>.

95 Shelley G Marshall, "Canadian Drug Policy and the Reproduction of Indigenous Inequities" (2015) 6:1 Intl Indigenous Policy $\mathrm{J}$ at 1 [citations omitted].

Supra note 1.

Jorge Barrera, "Cannabis: The New Tobacco?" CBC News (27 May 2018), online: <https://news interactives.cbc.ca/longform/cannabis-the-new-tobacco $>$. See also Canada, Standing Senate Committee on Aboriginal Peoples, The Subject Matter of Bill C-45: An Act Respecting Cannabis and to Amend the Controlled Drugs and Substances Act, the Criminal Code and Other Acts (Ottawa: Senate Canada, May 2018) at 8, online: $<$ https://sencanada.ca/content/sen/committee/421/APPA/reports/2018-05-01_BILLC45_Cannabis_e.pdf $>$ [Report of the Standing Committee] ("[ $\mathrm{t}$ ]he Committee strongly believes that under section $\overline{3} 5$ of the Constitution Act, 1982, Indigenous peoples have the inherent right of selfdetermination, including the appropriate law-making authority to make meaningful decisions that affect the lives of their people and communities, including regulating cannabis" at 14). 
as part of the Indian Residential Schools Settlement Agreement, the TRC conducted public hearings and collected more than 6,750 statements from survivors of residential schools, members of their families, and other individuals who wished to share their knowledge of the residential school system and its legacy. ${ }^{98}$ In 2015, the TRC presented its final report, which included 94 recommendations to further reconciliation between Canadians and Indigenous peoples. ${ }^{99}$ A number of these recommendations - or Calls to Action - are particularly relevant in the context of cannabis legalization.

With respect to economic development, the recommendations call on the federal government to develop with Aboriginal groups a joint strategy to eliminate employment gaps between Aboriginal and non-Aboriginal Canadians. ${ }^{100}$ The corporate sector in Canada is also called upon to ensure that Aboriginal peoples have equitable access to job opportunities, and that Aboriginal communities gain long-term sustainable benefits from economic development projects. ${ }^{101}$ In terms of criminal justice, the recommendations call on federal, provincial, and territorial governments to eliminate the overrepresentation of Aboriginal people in custody over the next decade. ${ }^{102}$

Underpinning these specific Calls to Action are recommendations that call for the reaffirmation of the nation-to-nation relationship between Aboriginal peoples and the Crown, including the repudiation of concepts used to justify European sovereignty over Indigenous lands and peoples; the renewal or establishment of Treaty relationships based on principles of mutual recognition and respect; and the reconciliation of Aboriginal and Crown constitutional and legal orders, including the recognition and integration of Indigenous laws and legal traditions in negotiation and implementation processes involving Treaties, land claims, and other constructive agreements. ${ }^{103}$ To this end, the government is also called upon to adopt and implement UNDRIP as the framework for reconciliation. ${ }^{104}$

In response to the publication of the TRC's final report, Prime Minister Trudeau stated that the Government of Canada would, "in partnership with Indigenous communities, the provinces, territories, and other vital partners, fully implement the Calls to Action of the Truth and Reconciliation Commission, starting with the implementation of the United Nations Declaration on the Rights of Indigenous Peoples." 105 Indeed, Canada formally

Truth and Reconciliation Commission of Canada, Honouring the Truth, Reconciling for the Future: Summary of the Final Report of the Truth and Reconciliation Commission of Canada (Ottawa: TRC, 2015 ) at 29.

TRC, Calls to Action, supra note 10 .

Ibid at Recommendation 7.

Ibid at Recommendation 92(ii).

Ibid at Recommendation 30.

Ibid at Recommendation 45

Ibid at Recommendations 43-44, 45(ii).

"Statement by Prime Minister on Release of the Final Report of the Truth and Reconciliation Commission" (15 December 2015), online: <https://pm.gc.ca/eng/news/2015/12/15/statement-primeminister-release-final-report-truth-and-reconciliation-commission $>$. 
removed its objector status to UNDRIP in May 2016. ${ }^{106}$ The government has since backed a bill calling for the full implementation of UNDRIP in Canadian law. ${ }^{107}$

UNDRIP contains provisions concerning Indigenous self-determination and development that are vitally important for reconciliation. Article 3 states that Indigenous peoples have the right to self-determination, and may freely determine their political status and pursue their economic, social, and cultural development. Similarly, Article 20(1) enshrines the right of Indigenous peoples "to maintain and develop their political, economic and social systems or institutions, to be secure in the enjoyment of their own means of subsistence and development, and to engage freely in all their traditional and other economic activities."108 UNDRIP also enshrines the rights of Indigenous peoples to maintain, control, protect, and develop their traditional knowledge, and the manifestations of their sciences, technologies, and cultures, including human and genetic resources, seeds, medicines, knowledge of the properties of flora, as well as the right to maintain, control, protect, and develop their intellectual property. ${ }^{109}$ In addition, "Indigenous peoples have the right to determine and develop priorities and strategies for the development or use of their lands or territories and other resources." 110

In light of the TRC recommendations and the provisions enshrined in UNDRIP, the shortcomings of Bill C-45 with respect to Indigenous peoples are particularly troubling, including with respect to criminal justice reforms, and economic and political selfdetermination. Indeed, a May 2018 report of the Standing Senate Committee on Aboriginal Peoples on Bill C-45 highlights five key concerns raised by Indigenous communities concerning the proposed legislation:

1. a lack of consultation with Indigenous communities and organizations in the development of Bill C45 ;

2. a lack of culturally specific public education materials on the legislation pertaining to the legalization of cannabis and on the health effects of cannabis;

3. a lack of access to, and funding for, culturally specific mental health and addictions services;

4. an imperative for action recognizing the inherent rights of Indigenous communities to exercise jurisdiction over the regulation, sale, consumption and taxation of cannabis in their communities; and

Tim Fontaine, "Canada Officially Adopts UN Declaration on Rights of Indigenous Peoples," CBC News (10 May 2016), online: <www.cbc.ca/news/indigenous/canada-adopting-implementing-un-rightsdeclaration-1.3575272>.

Bill C-262, An Act to ensure that the laws of Canada are in harmony with the United Nations Declaration on the Rights of Indigenous Peoples, 1st Sess, 42nd Parl, Canada, 2015-2016-2017-2018 (as passed by the House of Commons 30 May 2018). See also John Paul Tasker, "Liberal Government Backs Bill that Demands Full Implementation of UN Indigenous Rights Declaration," CBC News (21 November 2017), online: $<$ https://www.cbc.ca/news/politics/wilson-raybould-backs-undrip-bill-1.441 $2037>$.

108 UNDRIP, supra note 8, art 20(1).

109 Ibid, art 31(1).

110 Ibid, art 32(1). 
5. a desire from Indigenous communities to fully participate in the economic opportunities and own source revenue potential occasioned by the legalization of cannabis. ${ }^{111}$

With respect to consultation, the report noted that "[m]any Indigenous communities and organizations informed the Committee that they were not consulted on the subject matter of the bill," stating that

[t]here was an alarming lack of consultation particularly given this Government's stated intentions of developing a new relationship with Indigenous people, respecting section 35 Aboriginal and treaty rights recognized under the Constitution Act, 1982, and the rights of Indigenous communities to be consulted. ${ }^{112}$

Indeed, the failure on the part of the government to adequately consult with Indigenous communities taints all aspects of the new legislation, particularly in the context of the historic and continuing disparities and injustices noted above. In particular, the lack of consultation and subsequent application of the new legislation to Indigenous communities constitutes a failure on the part of the government to take these communities' self-determination seriously, and infringes the right of Indigenous peoples to freely determine their political status and freely pursue their economic, social, and cultural development under UNDRIP. ${ }^{113}$

In response, the Senate Committee called on the government to delay the coming into force of Bill C-45 for up to a year to allow time for broader consultations to be undertaken with Indigenous communities. ${ }^{114}$ A number of Indigenous leaders also called for the postponement of cannabis legalization, in order to allow communities more time to prepare for the changes. For example, chiefs of the Dene Nation asked the Liberal government to postpone legalizing cannabis for at least two years. ${ }^{115}$

The issue of self-determination is also closely linked to the economic aspects of the new legislation. While some Indigenous communities have sought to seize the economic opportunities that legal cannabis presents by establishing dispensaries, some of these retail operations have been deemed illegal and have been raided by the police. ${ }^{116}$ Under the new law, the regulation of cannabis production, distribution, and retail is the exclusive jurisdiction

111 Report of the Standing Committee, supra note 97 at 7.

112 Ibid at 8

113 UNDRIP, supra note 8, art 3.

114 Report of the Standing Committee, supra note 97 at 16.

115 CBC, "Dene Nation Calls on Feds," supra note 89; Katie Toth, "Cannabis as Colonialism? N.W.T. Woman Says Government Shouldn't 'Impose’ Legalization,” CBC News (2 May 2018), online: <www. cbc.ca/news/canada/north/nwt-communities-timeline-marijuana-1.4640884>.

116 See e.g. "Wahnapitae First Nation Pot Shops Raided by Police," CBC News (8 January 2019), online: $<$ https://www.cbc.ca/news/canada/sudbury/wahnapitae-first-nation-marijuana-dispensaries-raid-1. 4969565>; The Canadian Press, "Saskatchewan Justice Minister Says Indigenous Cannabis Store Illegal," National Post (16 November 2018), online: $<$ https://nationalpost.com/pmn/news-pmn/canadanews-pmn/saskatchewan-justice-minister-says-indigenous-cannabis-store-illegal $>$. In the run up to legalization, a number of Indigenous cannabis dispensaries were also raided. See e.g. Dale Carruthers, "First Nation Marijuana Shop Empty, Shuttered After Police Presence," The London Free Press (28 March 2018), online: <lfpress.com/news/local-news/first-nation-marijuana-shop-empty-shuttered-afterpolice-presence>; Beverly Andrews, "No Dispensaries: Wait Until Marijuana is Legal Says Six Nations Police Chief," APTN National News (22 January 2018), online: APTN < aptnnews.ca/2018/01/22/nodispensaries-wait-until-marijuana-is-legal-says-six-nations-police-chief/ $>$. 
of the provinces and territories, and First Nations are also excluded from any cut of the cannabis tax revenue. ${ }^{117}$

Thus, while in some parts of the country, companies that are either Indigenous-owned or have significant Indigenous involvement have been granted licenses as producers under the new rules, ${ }^{118}$ the provisions of the Cannabis Act effectively exclude Indigenous communities from making key economic and political decisions regarding cannabis on their own territories. Many have pointed out that the situation mirrors the battle between government and First Nations over the trade and sale of untaxed tobacco. ${ }^{119}$ According to Seth LeFort, the owner of Mohawk Medicine herbal dispensary in Six Nations, the government's move to criminalize much of the First Nations tobacco industry with Bill C-10 "essentially crushed the tobacco trade, which was originally started by traditional grassroots people but is now controlled by tobacco millionaires." ${ }^{20}$ LeFort notes that the "traditional people are again building the cannabis trade ... and this time they don't plan to lose control."121 The Kanien'kehá:ka community of Kahnawake, Quebec also hopes to avoid problems similar to those that arose with tobacco. In December 2018, the Mohawk Council of Kahnawà:ke enacted the Kahnawà:ke Cannabis Control Law, asserting its "exclusive right and jurisdiction to regulate and control cannabis within the Territory." 122

With respect to the criminal justice system, the new legislation is also inadequate. The Cannabis Act itself contains no amnesty provisions to pardon those convicted under existing marijuana laws, despite a history of inequity in the application of drug laws to Indigenous people and other racialized populations in Canada, and despite calls on the government by the TRC to remedy the over-criminalization of Indigenous peoples. ${ }^{123}$ On 17 October 2018 , the government did announce plans to pardon those convicted of simple marijuana possession; however, the legislation has not yet been tabled. ${ }^{124}$ Moreover, the pardon process leaves the onus on those seeking the pardon to complete the "onerous" process, and is more limited in its effects than a record expungement. ${ }^{125}$ For example, those with pardons are still required to indicate that they have been convicted of a criminal offence when applying for housing or employment, and US Customs and Border Protection does not recognize foreign pardons. ${ }^{126}$ The delay in passing legislation to facilitate pardons is also problematic because

John Paul Tasker, "First Nations Demanding a Cut of Cannabis Tax After Pot Legalization," CBC News (8 March 2018), online: <www.cbc.ca/news/politics/first-nations-cannabis-excise-tax-1.4564121>. Mark Rendell, "First Nations Entrepreneurs Big Winners of Manitoba Cannabis Plan," Financial Post (16 February 2018), online: < business.financialpost.com/business/first-nations-entrepreneurs-bigwinners-of-manitoba-cannabis-plan>; Lisa Campbell, "Indigenizing Cannabis: Quiet Revolution Grows as More First Nations Embrace Legalization," NOW Toronto (24 May 2018), online: <https://now toronto.com/news/cannabis-indigenous-communities-legalization/>.

Jorge Barrera, "First Nations Entrepreneurs Are Asserting Sovereignty and Seizing the New Cannabis Economy," CBC News (10 January 2018), online: <www.cbc.ca/news/indigenous/first-nationsentrepreneurs-are-asserting-sovereignty-and-seizing-the-new-cannabis-economy-1.4481747>. Ibid.

Ibid.

Kahnawà:ke Cannabis Control Law, KRL 2018, c C-4, online: <www.kahnawakemakingdecisions. com/legislation/laws/docs/CannabisControl.pdf $>$.

TRC, Calls to Action, supra note 10 at Recommendation 30.

John Paul Tasker, "Tens of Thousands of Canadians Could Soon Be Eligible for a Pot Pardon, But Lawyers Warn About Limitations," CBC News (18 October 2018), online: <https://www.cbc.ca/ news/politics/tasker-pot-pardons-limitations-1.4866610>.

Ibid.

Ibid. 
people with criminal records are currently not permitted to work in the cannabis industry, ${ }^{127}$ effectively excluding those hardest hit by prohibition from any of the economic benefits of legalization, and placing members of marginalized communities with a record for possession at a double disadvantage.

In contrast, other jurisdictions have taken a more progressive approach to cannabis legalization, attempting to redress some of the historical wrongs of prohibition. For example, the city of Oakland, California (where recreational marijuana sales were legalized state-wide on 1 January 2018) introduced a "special cannabis business permit program that prioritizes people with previous marijuana convictions who meet certain conditions," while Los Angeles is also implementing "a similar 'social equity' program to make the economic opportunities of legalization available to those who suffered most under prohibition." 128

In some respects, concerns over the new legislation's impact on Indigenous economic and political self-determination in Canada echo similar issues at the international level. In Canada and elsewhere, "theorizations of cannabis cultivation and use are inextricably bound up with broader understandings of power, knowledge, class, ethnicity, and the state." 229 In Indigenous cultures around the world, intertwined histories of colonialism and drug prohibition have led in many cases to the "militarization of psychoactive substance landscapes [placing] indigenous cultures on the front line of the war on drugs." ${ }^{130}$ In Canada too, Indigenous peoples "have been socially positioned for involvement with illicit substances and markets through racist social, historical, and legal practices, creating the conditions for problematic drug use, high surveillance, and criminal justice system encounters related to illicit drug offences." 131

As we have seen, the continuing legacy of drug regulation - and indeed, the very question of who has been able to define, classify, and regulate plants at all - has also created challenges at the international level with respect to the protection of plant genetic resources, traditional knowledge, and requirements of free, prior, and informed consent. Many of these same challenges may also arise in the Canadian context. For example, the regime for the protection of plant breeders' rights under the Plant Breeders' Rights Act reflects Canada's obligations under the 1991 UPOV Convention, and includes the same requirement that a plant variety must be new, different, uniform, and stable in order to receive protection. ${ }^{132}$ As demand for cannabis plant varieties continues to grow with legalization, the Plant Breeders' Rights Act will likely become important for underground breeders holding significant genetic resources and for corporate producers looking to get a market edge on the competition. Canadian requirements concerning the protection of traditional knowledge, and free, prior, and informed consent are also likely to come into play, posing challenges similar to those encountered at the international level.

Leyland Cecco, "Canada Plans to Legalize Weed - But Will Those Convicted of Crimes Get Amnesty?" The Guardian (8 May 2018), online: <https://www.theguardian.com/world/2018/may/07/ canada-marijuana-cannabis-legalization-amnesty-drug-laws $>$. theleafnews.com/news/making-amends-468883883.html>.

Warf, "High Points," supra note 15 at 418.

Steinberg, supra note 26 at 4.

Marshall, supra note 95 at 11 .

Plant Breeders’ Rights Act, SC 1990, c 20, s 4; UPOV Convention, supra note 36, arts 5-9. 


\section{CONCLuSion}

The development of a new framework for cannabis legalization in Canada holds tremendous potential as a step towards reconfiguring the relationships between First Nations, Métis, and Inuit peoples and Canadian legal and governmental institutions. In addition to the chance to redress past harms, such as the disproportionate impact of cannabis prohibition on Indigenous peoples in Canada, legalization is an opportunity for Indigenous communities to begin implementing their own economic and justice systems in a meaningful way. It is also an opportunity for Canada to implement the TRC's Calls to Action, as well as its commitment to adopt UNDRIP as a framework for reconciliation.

Unfortunately, the new legislation, as it currently stands, fails to seize these opportunities. It is inadequate both in terms of the lack of consultation with Indigenous communities, as well as in terms of the substantive provisions - and omissions - in the legislation itself.

It is also important to keep in mind that Canada's obligations - both moral and legal extend beyond national borders. Canada has been a participant in the "globalization of drug production and consumption,"133 as well as a key player in international drug prohibitions that have caused untold suffering around the world. ${ }^{134}$ Now, with cannabis legalization, many Canadian producers are poised to reap tremendous financial rewards from this newly licit industry, while the federal and provincial governments will benefit from the tax revenue. Yet many of the strains at the heart of this cannabis boom have been developed from landraces cultivated for generations by Indigenous and local communities around the world communities that have not been able to exercise their right to free, prior, and informed consent, and have not been compensated for their genetic resources and associated traditional knowledge.

All in all, the legalization of cannabis is an important first step towards redressing past harms, and presents Indigenous communities in Canada with new opportunities for greater political, economic, and cultural self-determination in the future. But if not handled carefully, and without the participation of Indigenous peoples as equal partners, legalization risks perpetuating injustices both in Canada and abroad. 
[this page is intentionally blank] 